\begin{tabular}{|l|l|l||}
\hline \multicolumn{2}{|c|}{ PublisherInfo } \\
\hline \hline PublisherName & $:$ & BioMed Central \\
\hline \hline PublisherLocation & $:$ & London \\
\hline \hline PublisherImprintName & $:$ & BioMed Central \\
\hline \hline
\end{tabular}

\title{
Ain't got rhythm
}

\begin{tabular}{|l|l|l||}
\hline \multicolumn{2}{|c|}{ ArticleInfo } \\
\hline \hline ArticleID & $:$ & 4695 \\
\hline \hline ArticleDOI & $:$ & $10.1186 /$ gb-spotlight-20030210-01 \\
\hline \hline ArticleCitationID & $:$ & spotlight-20030210-01 \\
\hline \hline ArticleSequenceNumber & $:$ & 47 \\
\hline \hline ArticleCategory & $:$ & Research news \\
\hline ArticleFirstPage & $:$ & 1 \\
\hline \hline ArticleLastPage & $:$ & 2 \\
\hline \hline & & RegistrationDate : 2003-2-10 \\
\hline ArticleHistory & $:$ & OnlineDate \\
\hline \hline ArticleCopyright & $:$ & BioMed Central Ltd2003 \\
\hline \hline ArticleGrants & $:$ & \\
\hline \hline ArticleContext & $:$ & 130594411 \\
\hline \hline
\end{tabular}


In the February 6 Nature Mohler et al. report the discovery of mutations in the gene encoding ankyrin-B (known as ankyrin 2) in patients suffering from cardiac arrhythmia and inherited long-QT syndrome (Nature 2003, 421:634-639). An A-to-G transition results in a glutamic acid-to-glycine substitution. Mice heterozygote for a null mutation in $A N K B$ also displayed cardiomyocyte defects, cardiac arrythmia and sudden death after exercise. The ankyrin-B protein appears to be important for regulating expression of the sodium pump, the sodium/calcium exchanger, inositol-1,4,5-triphospate receptors, as well as $\mathrm{Ca}^{2+}$ signalling. This is the first report of a mutation in congenital long-QT syndrome that affects a protein other than an ion channel or channel subunit.

\section{References}

1. Nature, [http://www.nature.com]

2. Ankyrins.

3. Molecular and cellular mechanisms of cardiac arrhythmias. 